\title{
Imaging the internal structure of Borelis schlumbergeri Reichel (1937): Advances by high-resolution hard X-ray microtomography
}

\author{
Siri K. Kellner, Michael W. Knappertsbusch, Loïc Costeur, \\ Bert Müller, and Georg Schulz
}

\begin{abstract}
We explored reconstructing the internal structure of an individual of the extant alveolinid larger benthic foraminifer Borelis schlumbergeri Reichel (1937) using highresolution hard X-ray microtomography $(\mu \mathrm{CT})$. Chamber segmentation analysis revealed a complex void architecture once filled by the living protoplasm beginning with a subsphaerical embryo (proloculus), surrounded by a streptospiral nepionic structure. It begins with Saturn-ring like, curved tubes perpendicular to each other. In late nepionic stage, they split up into an increasing number of chamberlets. Adult growth begins when streptospiral winding changes to planispiral coiling and the test starts stretching into the typical alveolinid fusiform shape. In the investigated individual the terminal chamber \#48 is subdivided in 71 chamberlets. In the terminal stage, chamber volume is reduced and chamber growth becomes irregular. The cell volume increases 7,584-fold from a prolocular size of $13,592 \mu \mathrm{m}^{3}$ to reach a cell volume of $103,077,248$ $\mu \mathrm{m}^{3}$, at a length of the protoplasmic body of $1,995 \mu \mathrm{m}$. $\mu \mathrm{CT}$ impressively illustrates the adaptive advantage of planispiral fusiform winding for squeezing a giant protoplasmic sheet into a compact and mechanically robust body without losing cellular connection from the interior to its periphery and still allowing endosymbionts to maintain photosynthetical function under high-energy shallow marine environments. The $\mu \mathrm{CT}$ data are compared with historical drawings and plasticine models of early alveolinid growth stages fabricated by micropaleontological pioneer Manfred Reichel in the 1930s, highlighting the unprecedented quality of structural analysis during those early days.
\end{abstract}

Siri K. Kellner. Museum für Naturkunde, Leibniz-Institut für Evolutions- und Biodiversitätsforschung, Invalidenstrasse 43, 10115-Berlin, Deutschland, Siri.Kellner@mfn.berlin

Michael W. Knappertsbusch. Natural History Museum Basel, Augustinergasse 2, 4001-Basel, Switzerland, Michael.knappertsbusch@unibas.ch

Loïc Costeur. Natural History Museum Basel, Augustinergasse 2, 4001-Basel, Switzerland,

Loic.costeur@bs.ch

Kellner, Siri K., Knappertsbusch, Michael W., Costeur, Loïc, Müller, Bert, and Schulz, Georg. 2019. Imaging the internal structure of Borelis schlumbergeri Reichel (1937): Advances by high-resolution hard X-ray microtomography Palaeontologia Electronica 22.1.17A 1-19. https://doi.org/10.26879/854

palaeo-electronica.org/content/2019/2471-borelis-micro-ct

Copyright: April 2019 Paleontological Society.

This is an open access article distributed under the terms of Attribution-NonCommercial-ShareAlike 4.0 International (CC BY-NC-SA 4.0 ), which permits users to copy and redistribute the material in any medium or format, provided it is not used for commercial purposes and the original author and source are credited, with indications if any changes are made.

creativecommons.org/licenses/by-nc-sa/4.0/ 
Bert Müller. University of Basel, Biomaterials Science Center, Gewerbestrasse 14, 4123 Allschwil, Switzerland, bert.mueller@unibas.ch

Georg Schulz, University of Basel, Biomaterials Science Center, Department of Biomedical Engineering, Gewerbestrasse 14, 4123 Allschwil, Switzerland, georg.schulz@unibas.ch

Keywords: X-ray microtomography; larger benthic foraminifera; ontogeny, growth analysis; Borelis schlumbergeri

Submission: 26 January 2018. Acceptance: 16 March 2019.

\section{INTRODUCTION}

Hard X-ray microtomography $(\mu \mathrm{CT})$ has experienced enormous progress in efficient $3 \mathrm{D}$ imaging with micrometer resolution and has been increasingly recognized as an indispensable tool by paleontologists (Cunningham et al., 2014; Hoffmann et al., 2014). Owing to the true micrometer resolution, the non-destructive technique is increasingly applied in micropaleontology, paleoceanography and other fields of earth sciences (Speijer et al., 2008; Abel et al., 2012; Görog et al., 2012; Masschaele et al., 2007; Briguglio et al., 2011; chapter 6 in Branson, 2014; Briguglio et al., 2013; Ferràndez-Cañadell et al., 2014; Briguglio et al., 2016; Schmidt et al., 2013; Johnstone and Barker, 2010; Cnudde and Boone, 2013).

The non-destructive technique is particularly amenable for studies of ontogeny, evolution and taxonomy of foraminifera if X-ray contrast between the test and the surrounding medium is high enough. Internal structures of these organisms are of prime importance to foraminiferal taxonomists and biostratigraphers ever since, including classical works of Carpenter, Parker and Jones, 1862; Van der Vlerk and Umbrove, 1927; Hofker, 1933, 1966, 1969 (and numerous further studies by that author); the famous studies of Reichel during the 1930s, (i.e., Reichel, 1931, 1933, 1937, 1941, 1953); Drooger, 1952 and 1984; Hottinger, 1963; and further examples given in Von Koenigswald et al., 1963; Hottinger, 1967; Van der Vlerk and Gloor, 1968; O'Herne, 1972; Schroeder, 1975; Van Gorsel, 1975; Schaub, 1981; Vicedo et al. 2009; Caus et al., 2013; Vicedo et al., 2013; Vicedo and Piuz (2017), to name but a few. The analysis of internal structures is usually accomplished on the basis of planar thin-sections, collected either from randomly oriented specimens in the case of indurated sediments or from oriented and serial sections of isolated individuals. However, their 3D reconstruction is often not easy, especially when structures are complex. Since the late 1950s micro-radiography became suitable to investigate the inner structure of foraminifera (Hedley, 1957; Bé et al., 1969; Langer, 1975; Leary and Hart, 1988; Mehl and Noe, 1990; Hottinger et al., 1991; and references in Green, 2001). Nevertheless, micro-radiography had no major breakthrough in micropaleontology mainly because of the limited spatial resolution (Mehl and Noe, 1990).

Occasionally, internal microstructures of foraminifers were derived and illustrated using special techniques including electron micrographs taken from araldite micro-casts (Hottinger, 1979; Hottinger and Leutenegger, 1980; Hottinger, Reiss, and Langer, 2001). Detailed internal and ontogenetic reconstructions remained. The preparation and data acquisition, however, was expensive. This laborious work resulted mostly from the limited imaginative power for complex 3D structures from series of 2D sections (Mehl and Noe, 1990). Yet, studies of juvenile-adult growth are necessary for a thorough understanding of the evolution of test architecture and size patterns, heterochrony and phylogenetic relationships between species in benthonic and planktonic foraminifera. This now seems better possibly due to the advances in $\mu \mathrm{CT}$, which became available to foraminiferologists since 2008 (Sasaki et al., 2008).

Using $\mu C T$, Görog et al. (2012) showed wellillustrated examples of miliolids (porcellaneous foraminifera). Miliolids form solid, imperforate walls, which give rise to high-contrast $\mu \mathrm{CT}$ images contrary to perforate foraminifera. Moreover, the alveolinids, which belong to miliolids, exhibit a characteristic planispiral-fusiform with an extremely complex internal architecture (Reichel 1931, 1933, 1937, 1941, 1953; Hottinger 1960 and 1974, Hottinger, 1983; Hottinger et al., 1993). This now appears to be a better possibly due to the advances in $\mu \mathrm{CT}$, which have become available to foraminiferologists since 2008 (Sasaki et al., 2008).

For these reasons and to explore this new technology, we have chosen a single specimen of the extant Borelis schlumbergeri Reichel (1937) for a pilot experiment. Following the classification 
scheme of the World Foraminifera Database (http:/ /marinespecies.org/foraminifera/index.php) the genus Borelis belongs to the family Alveolinidae Ehrenberg, 1839. According to Langer and Hottinger (2000), its structural characters were established by M. Reichel (1937) for the former generic name "Neoalveolina", but later were complemented by Hottinger et al. (1993).

The genus Borelis includes the two extant representatives $B$. schlumbergeri (Reichel, 1937) and B. pulchra (d'Orbigny, 1839). Taken together, they show a circumtropical and cosmopolitan biogeography (cit. in Langer and Hottinger, 2000; Hottinger, 1974), but on species level there is clear provincial distribution with $B$. pulchra apparently being restricted to the Caribbean area, and $B$. schlumbergeri occurring in the Red Sea, from the East African coast to Mauritius Island and the Maledives (Reiss and Hottinger, 1984).

Currently available $\mu \mathrm{CT}$-systems allow for the quantification of internal microstructures and the chamber voids once filled by the living protoplasm of the organism. The primary goal of the present study was to estimate the effort required to threedimensionally reconstruct the internal structure of an alveolinid using an isotropic voxel size of one micrometer. Such a basic study on one object permits the precise planning of a series of ontogenetic-statistical analyses on larger sets of foraminiferal species. We hypothesize that the contrast and the spatial resolution of the isotropic 3D data are matchless in the field of micropaleontology even for a single specimen.
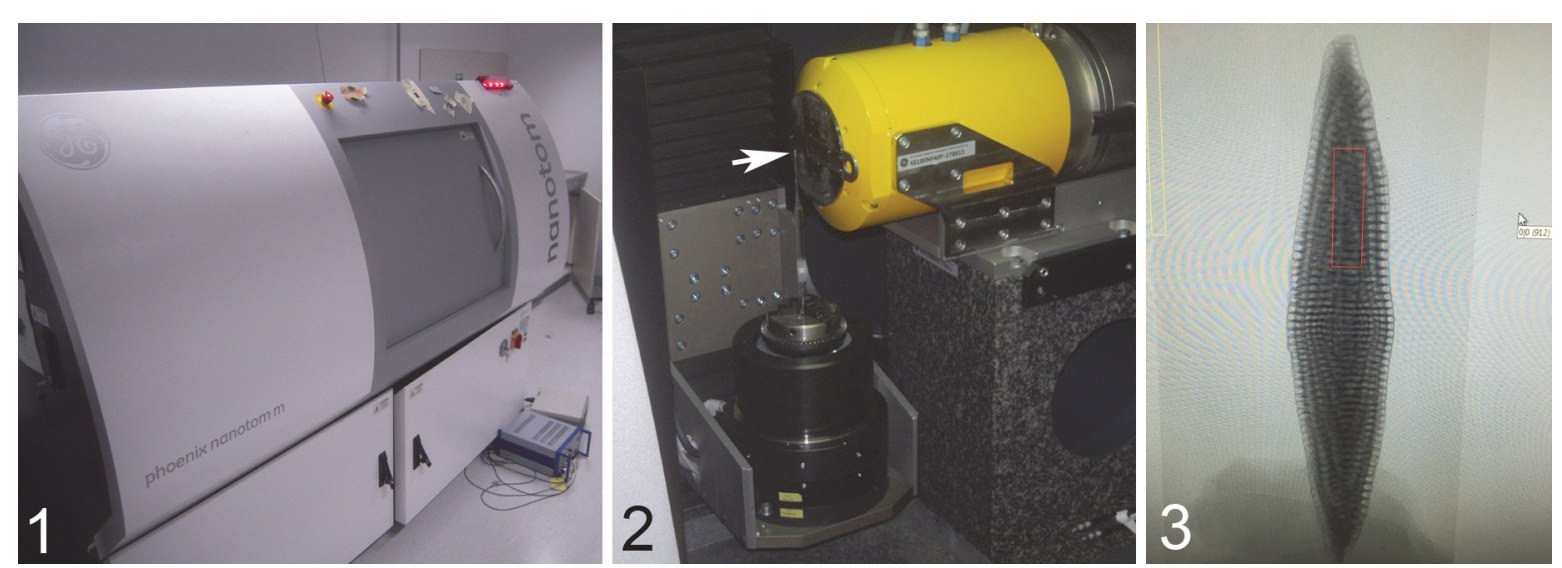

FIGURE 1. The $\mu$ CT-system nanotom $® \mathrm{~m}$. 2, Vertical placement of the glass pipette in front of the $\mathrm{X}$-ray source. White arrow points to the specimen. 3, Typical radiograph of the specimen taken from the screen. The glue is less $X-$ ray absorbing than the object of interest, see lower part of the image.

\section{MATERIALS AND METHODS}

\section{Specimen Selection and $\mu \mathrm{CT}$ Imaging}

The specimen 77023-1 of Borelis schlumbergeri Reichel was removed from a Fema-cell labelled "Alveolinella (B-Form)" containing several isolated recent alveolinid specimens from sample 77023 in the study collections of Lukas Hottinger deposited at the Natural History Museum of Basel (NMB). The sample was collected on Baros Island, Malé Atoll, Maldives (Lat. 4 17' 5.6" N / Long. 73 $\left.25^{\prime} 37.95^{\prime \prime} \mathrm{E}\right)$, at a water depth of $40 \mathrm{~m}$ in 1977 by Lukas Hottinger.

Specimen 77023-1 was vertically mounted on the tip of a shortened glass-pipette using water soluble paper glue Pritt from Henkel. The pipette was then transferred to the $\mu$ CT scanner and placed in a vertical position to achieve a working distance to the source between 1 and $2 \mathrm{~mm}$, cf. Figure 1. The $\mu C T$ imaging was performed using a nanotom $\circledast m$ (GE Sensing \& Inspection Technologies $\mathrm{GmbH}$, Wunstorf, Germany) equipped with a $180 \mathrm{kV} / 15 \mathrm{~W}$ high-power nano-focus $₫$ X-ray tube.

During about 4 hours, 1440 equiangular radiographs were taken along $360^{\circ}$. The accelerating voltage was set to $60 \mathrm{kV}$. The beam current corresponded to $410 \mu \mathrm{A}$. The effective pixel size of the radiographs amounted to $1.1 \mu \mathrm{m} \times 1.1 \mu \mathrm{m}$. The resulted reconstructed image stack comprised 2108 virtual slices each $473 \times 480$ pixels.

\section{Pre-processing, Segmentation, Rendering and 3D-Reconstruction}

The commercially available software AVIZO 7.0 from FEI Visualization Sciences Group was applied for the segmentation and rendering of the 
internal microstructures. To reduce the size of the dataset to 526 slices, only one out of four slices has been employed. Using AVIZO, the specimen was first segmented chamber-wise from one pole to the other one, i.e., parallel to the coiling axis of the specimen. Segmentation was started from the latest chamber, i.e., \#48, until the proloculus, i.e., \#0. In a second step, each chamber was labelled using a color code. The manual segmentation process required about one week. A video that illustrates the sequence of chamber fillings from the proloculus through to the terminal chamber was generated by means of the extended functions in AVIZO 8. In addition, axial, equatorial and tangential virtual sections were obtained by the software Voxler2 (http://www.goldensoftware.com/), to compare them with the historical drawings from alveolinid tests given in Reichel (1937) and Hottinger (1960).

Alternatively to the usage of AVIZO and Voxler software products, 3D reconstruction and visualization can be performed using open source Java ImageJ and/or Fiji plugins that were inspired by $\mathrm{NIH}$ Image initiative and which is in the public domain (https://imagej.net/), see also Schindelin et al., 2012). Particularly to visualize image stacks three-dimensionally and for volume rendering the ImageJ 3D Viewer can be applied (see http:// 3dviewer.neurofly.de). For segmentation of inner structures, the Segmentation Editor in ImageJ from Johannes Schindelin, Francois Kusztos and Benjamin Schmid can be used, see https://imagej.net/ Segmentation_Editor.

\section{Deposition of Specimen and Data}

The investigated specimen is deposited in the reference collection to this article at the NMB in Basel. The full and reduced image stacks as well as the AVIZO and Voxler2 generated networks can be downloaded as supplementary data at https:// doi.org/10.1594/PANGAEA.884663. A mirror of the same set of data is stored on the internal media server at the NMB.

\section{RESULTS}

\section{D Representation and Axial, Equatorial and Tangential Sections}

To describe the microstructural features, the structural terms of Reichel (1937) and Hottinger (1960, 1974, and 2006) are applied. The latter reference is also applied to terms of ontogenetic growth stages. Figure 2 displays the $\mu$ CT-data in four representations. These images show the structural elements of the elongated Borelis test including the apertural face with a single line of main apertures and without inter-calar apertures (in contrast to Alveolinella, which for example has multiple rows of supplementary apertures in the apertural face). The proloculus is surrounded by three whirls of irregularly (streptospirally) arranged chambers, cf. Figure 2.1 and 2.2. In the axial section, the more adult chambers are increasingly subdivided in chamberlets. A columnar structure is evident toward the two pole regions. In the equatorial section of Figure 2.3, the bending of the septum is easily visible. The preseptal passages occur before each septum as deep holes. There are no postseptal passages. The nepionic (juvenile) stage of the test having a more compressed and irregular arrangement of chambers can be easily distinguished from the ephebic (adult) stage until about the third whorl after the proloculus. The ephebic stage is characterized by regular planispiral coiling around the coiling axis and chambers get increasingly elongated. Until the gerontic or terminal stage our specimen has grown to a test length of 2,230 $\mu \mathrm{m}$ and a maximum diameter of $470 \mu \mathrm{m}$, and reached 49 chambers (the proloculus being counted as chamber \#0). Figure 3 shows an alternative volume rendering in axial section of the test from the same CT-data but using the Voxler2 software.

\section{Reconstruction of the Protoplasmic Body of Borelis}

Figure 4 displays a selection of ontogenetic reconstructions ranging from the nepionic cell until the adult individual. Figures 4.1 and 4.2 show the early and late stages of the nepiont, respectively. In Figures 4.3 and 4.4 , early-adult and mid-adult stages are given. Figure 4.5 represents the complete cell in side and polar views. Appendix 1 shows a video with the complete sequence of chamber addition. Further videos showing growth and internal architecture are presented in Appendix 2 and 3 in context with Figure 3, and Appendix 4 and 5 , in context with Figure 5.

The analysis of the juvenile cell body reveals the irregular growth of the nepiont ["le pelotonnement des premiers tours de spire" on page 81 in Reichel (1937); compare for example also with illustrations given in Sirel and Acar (1982) for the case of Praebullalveolina]. The nepiont is followed by the planispiral and more regular coiling of the adult organism. In this specimen, the nepiont begins with a sub-spherical proloculus, which is followed by three curved tubes, that coil more or less 

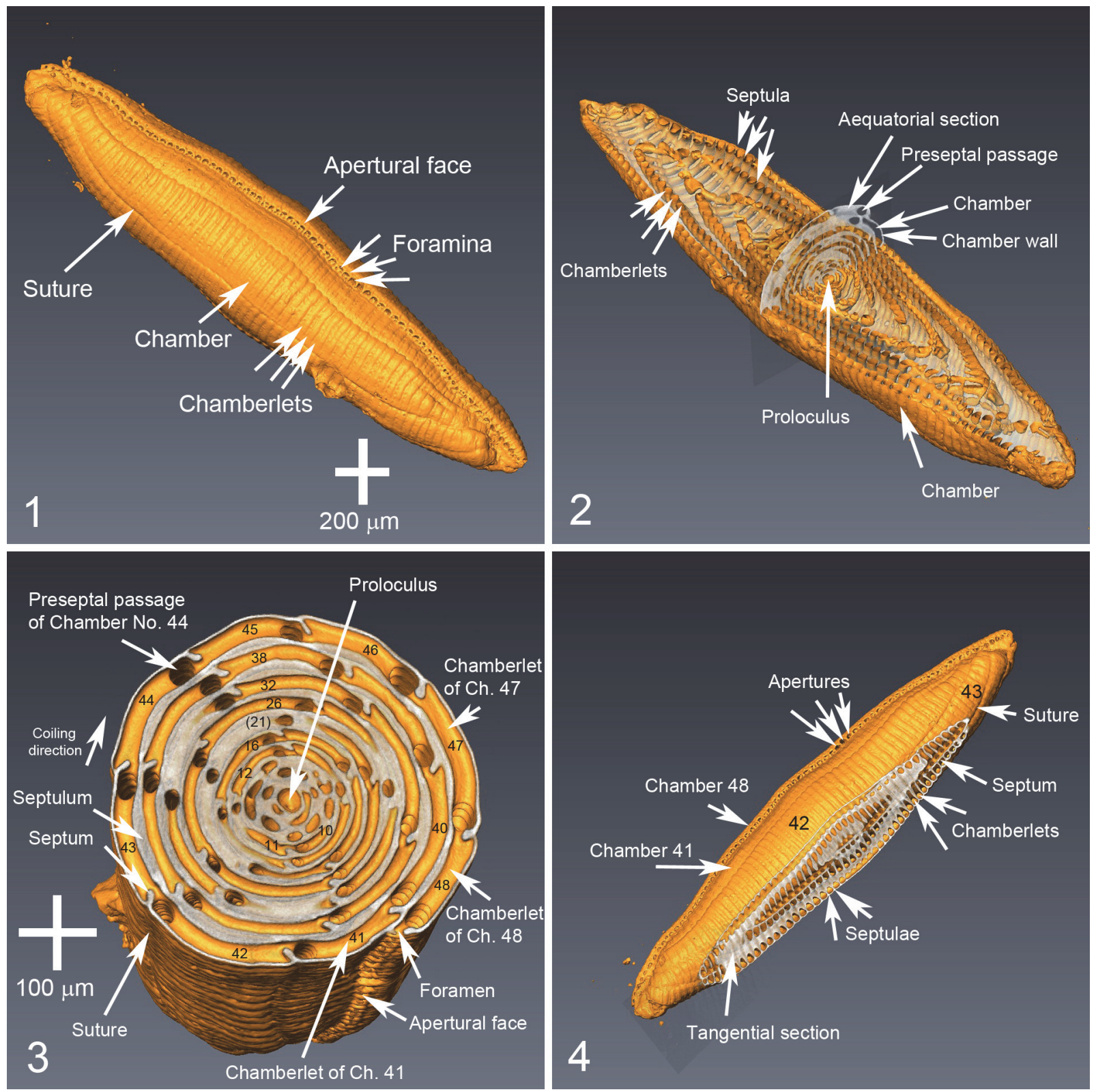

FIGURE 2. Representations of the $\mu$ CT-data of Borelis schlumbergeri Reichel (1937), specimen 77023-1 using AVIZO 7 software. 1, External view of test showing chamber sutures and the apertural face with a single row of main apertures. 2, Axial section through the proloculus showing the calcareous test material as greyed material (slightly transparent) and empty spaces of chambers with chamberlets in orange color. 3, Equatorial section through the proloculus in slight oblique view. Again, the test material is colored in grey and empty spaces (chambers) in orange. Preseptal passages are easily recognized in the regularly coiled portion of the test as deep holes before every septum. The nepiont is recognized by its more irregular arrangement of chambers within the first three coilings around the proloculus. Black numerals indicate the same chamber numbers as in Figure 4 below. Note, that in the equatorial section, the chambers are represented by sections through chamberlets. The bracketed chamber number (21) indicates a section through a septulum wall. 4, Tangential section through chambers 45 and 46 illustrating direct, non-alternating arrangement of septulae. Horizontal and vertical scale-bars in Figure 2.1 and Figure 2.3 represent $200 \mu \mathrm{m}$ and $100 \mu \mathrm{m}$, respectively.

perpendicular to each other around the proloculus in a Saturn ring-like manner, cf. Figure 4.1. During this stage, the individual chambers can be distinguished by the constrictions in the tubes, see arrows in Figure 4.1. The first chamber after the proloculus (=deuteroconch) occupies $1 / 2$ cycle around the proloculus. The next four chambers increase in length and also occupy half a cycle 


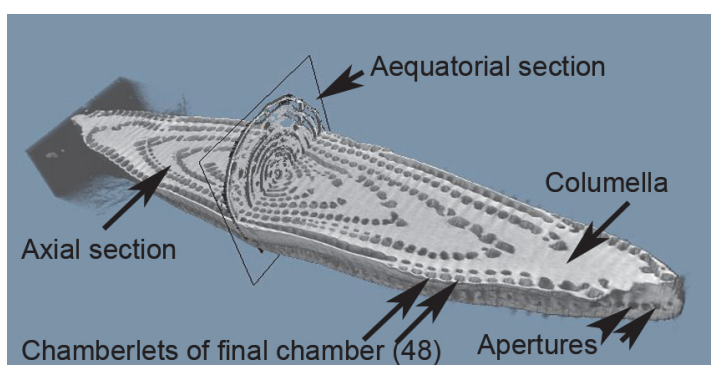

FIGURE 3. Axial section of Borelis schlumbergeri (specimen 77023-1) through a reduced image stack, i.e., every fourth image used, illustrating the subdivision of chambers into arrays of chamberlets. Outer chambers show a regular arrangement around the coiling axis with a simultaneous elongation of the chamber form. The vertical plane is an equatorial section through the proloculus. Visualization done using Voxler2 software. See Appendix 2 and 3 for launching an animation through the axial sections (Appendix 2 in avi format, Appendix 3 in gif format).

around the proloculus. Every two neighboring, tube-like chambers form a full circle that is arranged in changing planes around the initial chamber and is termed streptospiral winding.

From chamber \#6 onwards, the chambers are getting subdivided into chamberlets with a bifurcation into a pair of chamberlets until chamber \#8, cf. Figure 4.2. The following two chambers, i.e., \#9 and \#10, are subdivided into four chamberlets. They surround the inner part of the cell but still show streptospiral winding of chambers. Thereafter, the number of chamberlets increases in several steps until more than 70 chamberlets are attained.

Chamberlets and spaces in between them are in alignment from one chamber to the next ("mode continu des cloisonnettes" in Reichel, 1937), which is a diagnostic feature of Borelis, see Figure 4.3. The stage, which in thin sections has often been referred to as the "peloton", can be interpreted as the moment when chambers begin to subdivide into chamberlets, i.e., here chamber \#6, and the end of streptospiral arrangement of chambers, i.e., chamber \#11 in the present case. Regular planispiral coiling, which marks the beginning of adult growth (ephebic stage) and the onset of the typical elongate-fusiform shape, begins with chamber \#12, cf. Figure 4.3.

The spacing between chamberlets in each chamber remains astonishingly regular with the exception of minor thickenings and fusions of chamberlets in chambers \#45 (yellow) and \#46 (blue), see Figure 4.6. These irregularities may be caused by cell lesion possibly during a storm event, when the animal was perhaps displaced from its substrate. Figure 5 illustrates the relationship between the arrangement of the protoplasmic filling and architecture of the solid, imperforate calcite test.

\section{Dimorphism: Megalospheric or Microspheric?}

Alveolinids show often prominent dimorphism, i.e., development of a megalospheric ("A-form") or a microspheric ("B-form") generation of tests. The megalospheric nepiont of large alveolinids (as for example in Alveolina) consists of a single, spherical and large initial chamber, with the second chamber already exhibiting the generotypic internal subdivision, and the coiling axis is already fixed in the final planispiral direction (cit. Hottinger, 1974, p. 22, see also Figure 6.6 and 6.7 below). In contrast, microspheric nepionts have a very small spherical proloculus followed by streptospirally coiled whorls prior to planispiral winding (Hottinger, 1974). In contrast, in Borelis dimorphism is reported to be absent or weak, with proloculi being small (Reichel, 1937; Hottinger, 1974). Considering the presented $\mu C T$-reconstructions the question concerning dimorphism in Borelis cannot be answered without statistical analyses on many specimens. However and leaning to the example of Alveolina, the observed internal structure (i.e., a spherical proloculus followed by streptospiral whorls prior to onset of planispiral winding) would plead for a microspheric ("B-form") expression of the present Borelis individual.

\section{Comparison of Borelis $\mu \mathrm{CT}$-Data with Historical Drawings and Models from Thin Sections}

The internal Bauplan of an alveolinid described above has been extensively documented by serial sections in a series of pioneering studies (Reichel, 1931 through 1937, 1941, 1953; Hottinger 1960, 1974). A $\mu C T$-study of the internal microstructures of alveolinids, however, is not reported yet. A potential reason for this lack lies in the fact that the majority of alveolinids has been found in Cretaceous to Paleogene shallow water carbonate platform deposits and Alveolina-limestones, where the cavities became filled by carbonate cement during diagenesis, which prevents $\mu \mathrm{CT}$ imaging with common photon energies.

In order to draw attention to the stunning development of methodologies in micropaleontology, it is tempting to search and compare early studies about the inner structure and nepiont reconstructions of Borelis with the results pre- 

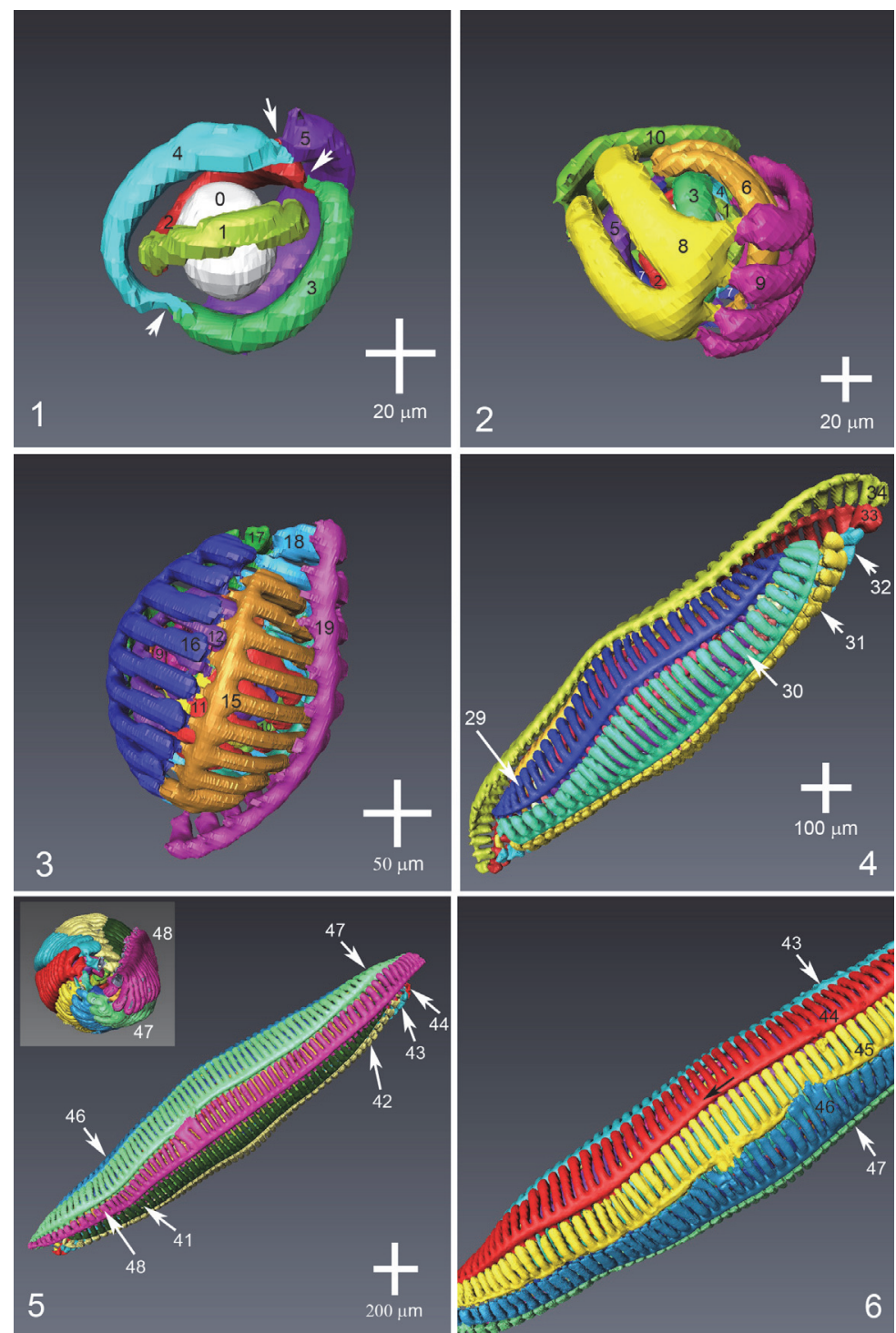

FIGURE 4. Reconstruction of the chamber voids representing the protoplasmic fillings of Borelis schlumbergeri (specimen 77023-1). 1, Early nepiont showing the proloculus and the first $2 \frac{1}{2}$ volutions, just prior to duplication of chambers into chamberlets (splitting into chamberlets begins in chamber \# 6). The chambers in that stage are curved tubes and are arranged in three almost perpendicular planes around the proloculus. Color coding: White = proloculus; green (chamber \#1) = deuteroconch; chambers \#2 (red), \#3 (blue-green), \#4 (cyan) and \#5 (blue) are juvenile chambers. Arrows point to constrictions between successive chambers. 2, Late nepionic stage beginning with chamber \#6, where the division of chambers into chamberlets begins. Chambers \#6 (orange), \#7 (green) and \#8 (yellow) are the first chambers with two chamberlets. Chamber \#9 is the first chamber showing four chamberlets. 3, Early ephebic (adult) stage, where planispiral arrangement of chambers, elongated growth of chambers and fusiform shape are already clearly visible. Please note the continual arrangement of chamberlets and spaces in between them from one chamber to the next, which is an important diagnostic feature and which is particularly well recognizable in this view. 4, Mid-adult stage until chamber \#34 (bright green). 5, Complete cell (gerontic stage) until chamber \#48 (pink). During the gerontic stage the growth rate becomes reduced and structural irregularities occur (Hottinger, 2006). The total length of the reconstructed soft cell-body is $1995 \mu \mathrm{m}$. The inset illustrates the pole view. 6, Detail of the late adult cell showing thickened and fused chamberlets in chamber \#45 (yellow) and \#46 (blue), possibly indicating cell lesion perhaps after a storm event. Black arrow indicates the preseptal passage string of cytoplasm connecting all chamberlets of chamber \#44. Vertical and horizontal scale-bars (in $\mu \mathrm{m}$ ) indicate decreasing magnifications. For launching an animation showing the chamber addition from proloculus to the adult stage see Appendix 1. A high-resolution version of this animation is provided in Appendix 4. A further video given in Appendix 5 illustrates the combination of axial sections and lateral views of chamber fillings from adult to juvenile stages. 

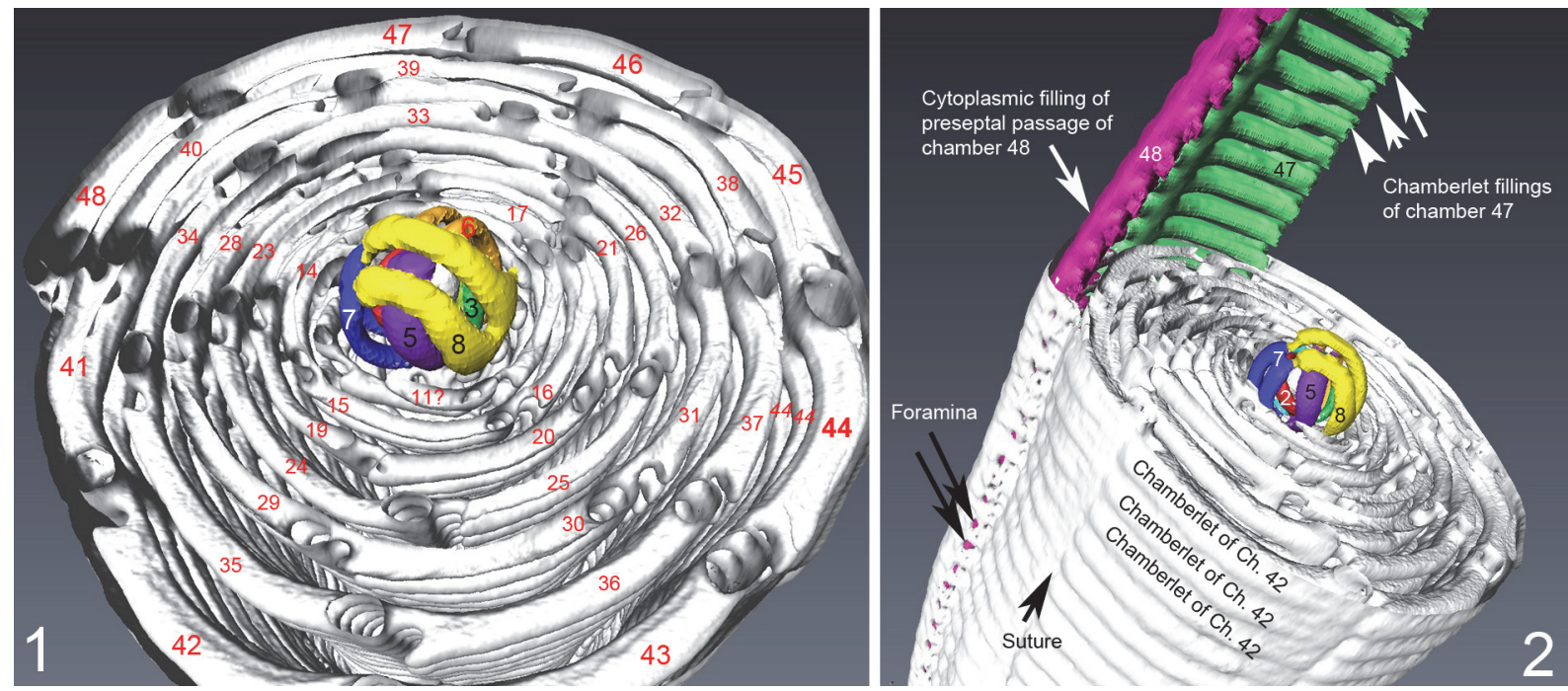

FIGURE 5. Relationship between reconstructed protoplasm and test in Borelis schlumbergeri specimen 77023-1. 1, Position of the late nepionic cell in the remaining part of the test. Yellow=chamber\#8. Chambers of juvenarium indicated with black and white numerals, chambers otherwise are indicated with red numerals. Note that only the uppermost chamberlet of each chamber is labelled; chamberlets of the same chamber appear in this perspective as stacked series (see for example the visible three chamberlets of chamber \#44, where the lower two chamberlets are labelled in italics and the uppermost chamberlet of chamber \#44 is indicated in bold). 2, Emplacement of the protoplasm in chamber \#47 (green) and chamber \#48 (pink) in the adult portion of the test. The protoplasmic stream filling the preseptal passages interconnect chamberlets within a single chamber. From this "preseptal string" cytoplasm transverses through apertures from one chamber to the next as can be seen in the main apertures along the apertural face of the test.

sented herein. In the scientific legacy of Manfred Reichel, which is deposited in the geological archive of the NMB, a few unpublished drawings (Figures 6.1 and 6.2) were found, that are of interest in this context. They are reproduced here to illustrate the outstanding quality of Reichel's ultrastructural representations from serial sections. In addition, Reichel manufactured a suite of plasticine, wooden or porcelain models of alveolinids and other foraminifera for research and teaching purposes. The majority of them are held in the micropaleontological collections of the NMB, while a smaller selection still resides in the micropaleontological teaching collections at the GeologicalPaleontological Institute of the University of Basel. Figures 6.3 and 6.4 are two examples of such plasticine models showing the inner structure of Borelis, while Figure 6.6 is a wooden model of Borelis, also made by Reichel. Figure 6.5 is a model from the Reichel-Hottinger collection of structural foraminiferal models representing the "sarcode" from two neighboring chambers with chamberlets in straight alignment, as it occurs in Borelis with the cytoplasm reconstructions shown in Figure 4. In this context the old term "sarcode" (synonym for protoplasm, see Hottinger, 2006) is used in order to refer to the original labelling in the collection and to remember its frequent usage by Reichel. In order to illustrate the differences of early ontogenetic structures of Borelis against other alveolinids, a structural model of the early stages of a Paleocene-Eocene Alveolina (macrospheric, "A-form") is shown in Figure 6.7, where streptospiral winding within the early nepiont is absent.

\section{Analysis of Growth}

The $\mu \mathrm{CT}$ data allow in an unprecedented manner for the quantification of the cell growth by measuring the volumes of the individual chambers. With the exceptions of a few recent studies on foraminifera (Speijer et al., 2008; Schmidt et al., 2013), this kind of quantitative analysis was previously impossible. Usually, ontogenetic growth was investigated from the 1930s onward in larger benthonic foraminifera in thin sections. The growth is frequently quantified by $2 \mathrm{D}$ plots of equatorial chamber areas, diameters or radii from the proloculus to the center of a chamber as function of successive instars (chambers), but these measurements allow only estimates for the volume increase of chambers. The same 2D technique was occasionally applied in planktonic foraminifera (Brummer and Kroon, 1988; Brown, 2007; Mary, 2013), but has the same limitations if one is out to measure true 

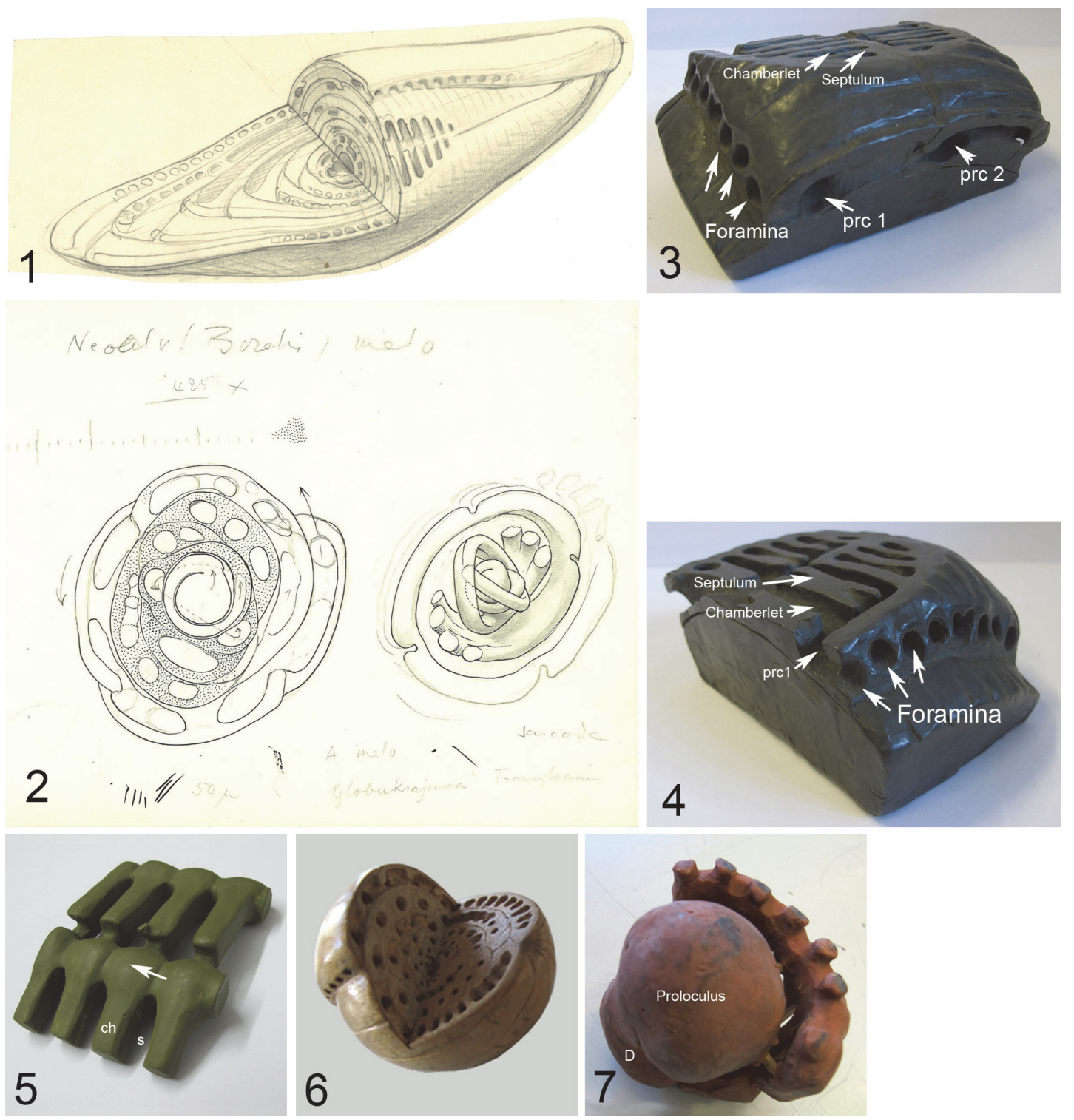

FIGURE 6. Manfred Reichel's reconstructions of Borelis and other alveolinids. 1, An early version of the reconstruction of Borelis schlumbergeri, that led to the published illustration of figure VIb (Neoalveolina schlumbergeri) on Plate XI in Reichel (1937). 2, Unpublished drawing of an equatorial section (left drawing) and a reconstruction of the nepiont of Borelis (Neoalveolina) melo (right drawing). Reichel's nepionic "sarcode" reconstruction based on thin-section analysis shows the irregular arrangement of chambers in the "peloton" and is surprisingly similar to the present $\mu C T$ results from Borelis schlumbergeri, cf. Figures 5 and 6. Both drawings are undated (probably drawn between 1931 and 1937, deposited in the geological archive of the Natural History Museum Basel). 3, and 4, Plasticine structural model for Borelis shown from two different views, fabricated by Manfred Reichel in the 1930s. Dimensions of the model $11 \mathrm{~cm} \times 7 \mathrm{~cm} \times 4 \mathrm{~cm}$. prc1 denotes the preseptal canal of the ultimate chamber, prc2 denotes the preseptal canal of the penultimate chamber. The spatial arrangements of the preseptal passage, the main apertural openings along the apertural face and chamberlets in a tangential section are best shown in Figure 6.4. 5, Undated "sarcode"model fabricated by $\mathrm{M}$. Reichel with gypsum from casts showing chamberlets (ch) and septulae (s) of two neighboring chambers in continuous alignment ("mode continue" des cloisonnettes in Reichel, 1937) as is observed in Borelis. Dimensions $10 \mathrm{~cm} \times 7.5 \mathrm{~cm} \times 3 \mathrm{~cm}$. The arrow indicates the "sarcode" (protoplasmic) stri ng through a preseptal passage. 6, Wooden model of Borelis made by M. Reichel. Dimension $6 \mathrm{~cm} \times 5.6 \mathrm{~cm} \times 4.8 \mathrm{~cm}$. 7, Proximal view of the nepiont and early adult chambers of a Paleocene to Eocene Alveolina to illustrate differences in the ultra-structures observed in Borelis. This model was also prepared by Manfred Reichel. Dimension $7.5 \mathrm{~cm} \times 5.5 \mathrm{~cm} \times 5.5 \mathrm{~cm}$. Models shown in Figures 6.3, 6.4, and 6.5 are deposited in the Collection of Foraminiferal Models of M. Reichel and L. Hottinger at the Natural History Museum, Basel. Models in Figures 6.6 and 6.7 are held in the micropaleontological teaching collections of the Geological-Paleontological Institute, University of Basel. 

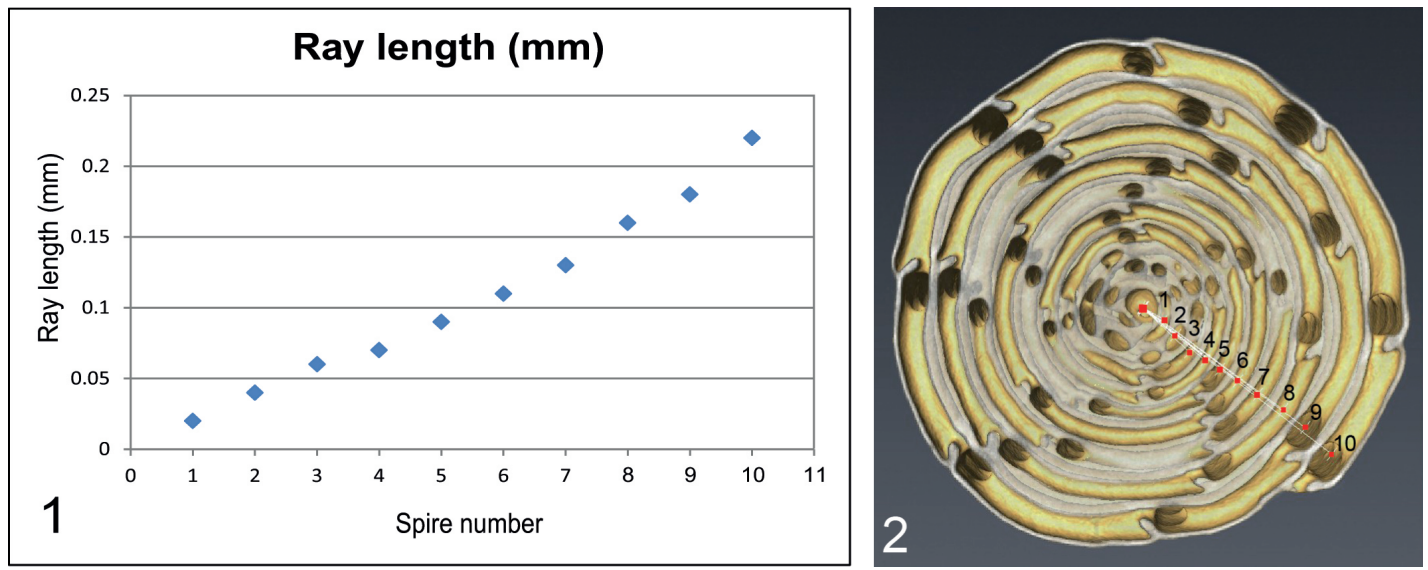

FIGURE 7. Spiral diagram for specimen 77023 of Borelis schlumbergeri investigated herein. 1, Plot of ray length versus the number of spiral whorls in the equatorial section (virtual slice\#1050 in AVIZO). 2, Equatorial section of specimen 77023 with the sphaerical proloculus in the center. For measurements see Table 1.

volumetric growth-rates. In the case of larger benthic foraminifera spiral diagrams (plots of the radius from the proloculus to the chamber in equatorial view versus the number of spiral whorl) next to other linear morphometric measurements became standard in taxonomic monographs, cf. Figure 7 and Table 1. These diagrams often form the basis for numeric classification and derivation of phylogenetic diagrams (Hottinger, 1960; Schaub, 1981).

The growth curves of true chamber volume can be more informative about the history of an individual than traditional spiral diagrams. Additionally, they are more accurate than the approximated 2D growth curves from microdissection analyses. Volume growth curves allow for precise measurements of cytoplasmic increase during ontogenetic maturation of the cell. In this perspective they may provide insight to processes controlling the physio-

TABLE 1. Measurements of ray lengths $(\mathrm{mm})$ for spire numbers 1 through 10 illustrated in Figure 7.

\begin{tabular}{cc}
\hline $\begin{array}{c}\text { Spire } \\
\text { number }\end{array}$ & $\begin{array}{c}\text { Ray length } \\
(\mathbf{m m})\end{array}$ \\
\hline 1 & 0.02 \\
2 & 0.04 \\
3 & 0.06 \\
4 & 0.07 \\
5 & 0.09 \\
6 & 0.11 \\
7 & 0.13 \\
8 & 0.16 \\
9 & 0.18 \\
10 & 0.22 \\
\hline
\end{tabular}

logical state of the cell, the role of endosymbionts, light, exchange of nutrients, and even may allow for modeling metabolic budgets of the cell. In the case of alveolinids recording the beginning of chamberlet formation allows bracketing of ontogenetic growth stages of the cell. Unfortunately, no time series of environmental conditions are available for the specimen presented here. However, the volume growth curve, the pattern of the increasing of number of chamberlets combined with the above structural reconstructions for specimen 77023 of $B$. schlumbergeri may point to possible environmental interpretations, see diagram in Figure 8 and Table 2:

- There is a 7,584-fold volume increase (from 13,592 $\mu \mathrm{m}^{3}$ to a total sum of chamber volume of $103,077,248 \mu \mathrm{m}^{3}$ ) from the proloculus through chamber \#48.

- The differential volume growth curve shows a largest volume of $4,798,600 \mu^{3}$ in the penultimate chamber \#47, which drops to a volume of 2,978,140 $\mu \mathrm{m}^{3}$ in the ultimate chamber \#48.

- $\quad$ There are two maxima (chambers \#44 and \#47) characterizing the gerontic stage. The minimum volume at chamber \#45 corresponds to the yellow-colored chamber in Figure 4.6 with fused chamberlets. Interestingly, the increase of number of chamberlets during that growth phase came to a halt (chamberlets \#44 to \#47) and could perhaps be caused by a cell-lesion from strong water movements during a storm event. A similarly irregular pattern is also observable the last chamber. Thickenings of tests due to wave exposure has been observed in the benthonic foraminifera Amphistegina lobifera and $A$. lessoni (Ter Kuile and Erez, 1984). 


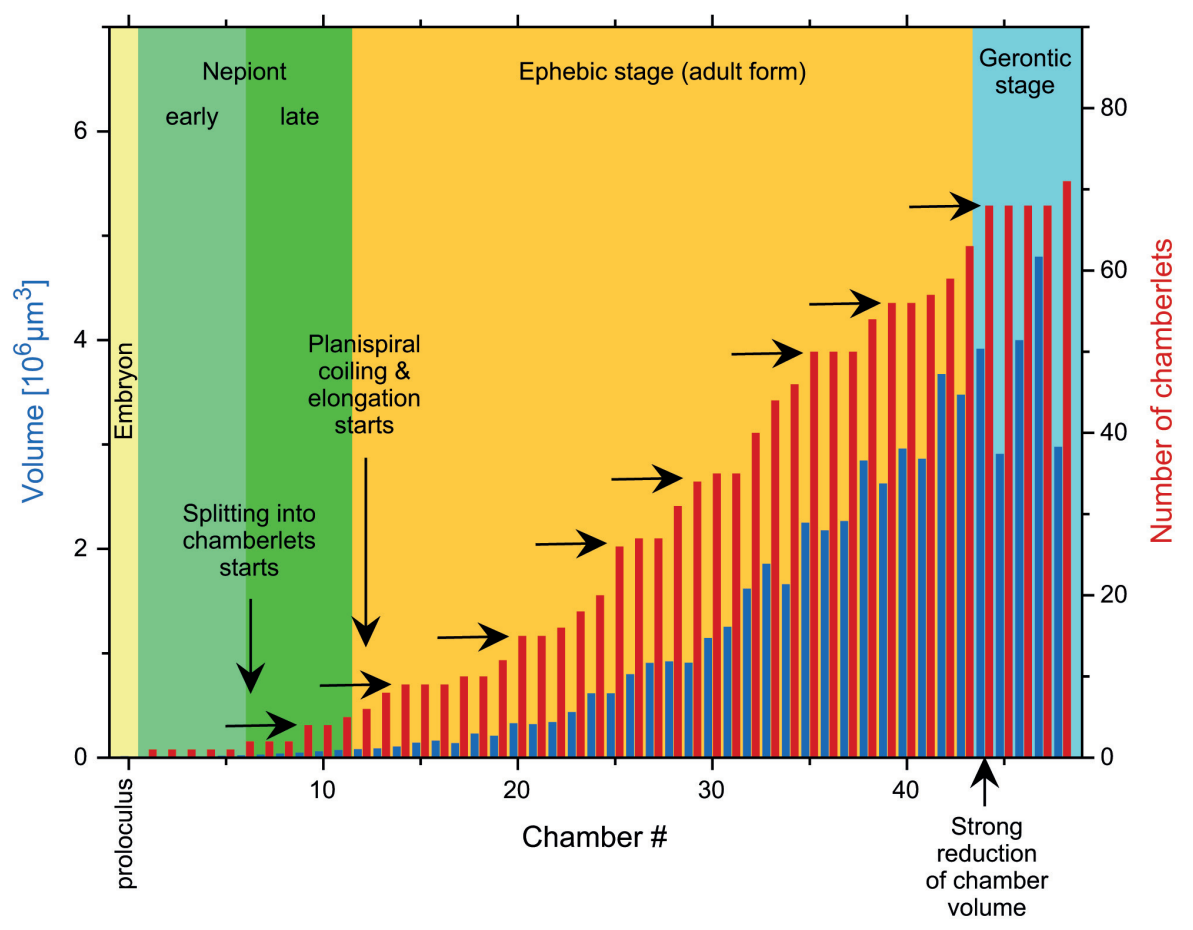

FIGURE 8. Volume growth curve (blue-colored bars) and increase of chamberlets per chamber (red-colored bars) for the investigated specimen 77023 of Borelis schlumbergeri from the proloculus through the last chamber. Terminology of foraminiferal growth stages from Hottinger (2006). The volume measurements and number of chamberlets per chamber are stored in Table 2.

- $\quad$ Each chamber is increasingly subdivided into chamberlets as the individual gets maturized: The increase of number of chamberlets per chamber follows roughly the volume growth curve, but the number of chamberlets is always either increasing or remains constant, never decreases. The ultimate chamber \#48 attains the highest number of chamberlets, namely 71. Most interestingly, there are several discrete plateaus, where the number of chamberlets in subsequent chambers stays constant and one gets the impression that the cell keeps repeatedly in quitescence for recovery until it continues to grow further.

\section{DISCUSSION AND CONCLUSION}

\section{Taxonomic Identification of Specimen $\mathbf{7 7 0 2 3}$}

Although it was originally deposited in a Fema-cell labelled as "Alveolinella (Forme B)", the structural observations described above confirm that the specimen 77023 belongs to Borelis schlumbergeri Reichel 1937. This finding is, inter alia, based on the single row of main apertures on the apertural face - in contrast to multiple rows of main apertures in the case of Alveolinella, and the irregular coiling of nepionic chambers - in contrast to a regular coiling of initial chambers in the case of Alveolinella.

\section{Growth of Chamberlets}

Borelis is known to inhabit back-reef coral-reef rubble, coral sand, and plant substrates until to approximately $40 \mathrm{~m}$ water-depth (Langer and Hottinger, 2000). Borelis - and its companion Alveolinella - hosts photosynthetic diatom endosymbionts in its cytoplasm (Leutenegger, 1984; Hottinger, 1977a; Renema, 2002; Hohenegger, 2009), which is unique to the imperforate larger foraminifera, but common in many perforate foraminiferal taxa (Langer and Hottinger, 2000). Larger benthic symbiont bearing foraminifera act like greenhouses; they are adapted to various light climates in their ambient marine environment, must resist noxious UV irradiation to prevent damage of symbiont algae and to the cell nucleus, and need at the same time enough stability to resist wave action (see review in Hohenegger, 1999). In this context, bauplan of Borelis schlumbergeri is a perfect adaptation to sun-lit, tropical shallow water environment. In the latest whorl of the test chamberlets are closest to the surface of the test. Cytoplasm and the symbionts living in there are most exposed to sun- 
TABLE 2. Chamber volume measurements in $\mu \mathrm{m}^{3}$, chamberlet number per chamber, and first derivative of chamberlet number from the proloculus (chamber \#0) through chamber \#48 illustrated in Figure 8.

\begin{tabular}{|c|c|c|c|}
\hline Chamber \# & $\begin{array}{c}\text { Chamber volume } \\
{[\mu \mathrm{m} 3]}\end{array}$ & $\begin{array}{c}\text { Chamberlet } \\
\text { Number }\end{array}$ & $\begin{array}{l}\text { First derivative of } \\
\text { Chamberlet Number }\end{array}$ \\
\hline Chamber48 & 2978140 & 71 & 3 \\
\hline Chamber47 & 4798600 & 68 & 0 \\
\hline Chamber46 & 3998420 & 68 & 0 \\
\hline Chamber45 & 2909540 & 68 & 0 \\
\hline Chamber44 & 3917572 & 68 & 5 \\
\hline Chamber43 & 3476996 & 63 & 4 \\
\hline Chamber42 & 3674272 & 59 & 2 \\
\hline Chamber41 & 2862640 & 57 & 1 \\
\hline Chamber40 & 2960680 & 56 & 0 \\
\hline Chamber39 & 2626536 & 56 & 2 \\
\hline Chamber38 & 2846244 & 54 & 4 \\
\hline Chamber37 & 2265984 & 50 & 0 \\
\hline Chamber36 & 2177916 & 50 & 0 \\
\hline Chamber35 & 2250584 & 50 & 4 \\
\hline Chamber34 & 1661328 & 46 & 2 \\
\hline Chamber33 & 1857572 & 44 & 4 \\
\hline Chamber32 & 1618548 & 40 & 5 \\
\hline Chamber31 & 1253148 & 35 & 0 \\
\hline Chamber30 & 1146348 & 35 & 1 \\
\hline Chamber29 & 909852 & 34 & 3 \\
\hline Chamber28 & 922036 & 31 & 4 \\
\hline Chamber27 & 908340 & 27 & 0 \\
\hline Chamber26 & 799456 & 27 & 1 \\
\hline Chamber25 & 616468 & 26 & 6 \\
\hline
\end{tabular}

light and UV-irradiation penetrating the water and the test wall. The porcelain wall that attenuates and diffuses direct sunlight irradiation ideally protects these portions of the cell but allows passing enough light for photosynthetic activity of the symbionts. More sensible functional parts of the cell like the nucleus, is protected from UV-irradiation deep in the center of the test. The steady increase of number of chamberlets during ontogenetic growth might signify a differentiation of the cytoplasma from areas inside the cell towards its periphery. Increased splitting of chambers into chamberlets may also allow photosynthetic endosymbionts for better proliferation and mobility while the foraminifer grows to larger cell size. Chlorophyll bearing symbionts may thereby have a tendency to move, or are passively dragged by the foraminiferan's flowing cytoplasm, between chamberlets to ideal spots beneath the test surface for best exposure to the sunlight's spectral irradiation. It would not be a surprise if more symbionts inside the test have possibly modified light absorption spectra than those inhabiting the periphery of the test.

The observed repeated conspicuous plateaus in the curve of number of chamberlets versus chamber number may be interpreted as temporary interruptions of growth, perhaps accompanied by exchange/acquisition of new symbionts. However, whether such deceleration has to do with diurnal to monthly cycles of irradiation, cloudiness, other environmental influences, dormancy or physiological reconstitution of the cell needs to be examined in life experiments.

At the same time, subdivision of the planispiral chambers into chamberlets is an efficient adaptation to allow the cell to grow rapidly, host as many 
TABLE 2 (continued).

\begin{tabular}{|c|c|c|c|}
\hline Chamber \# & $\begin{array}{c}\text { Chamber volume } \\
{[\mu \mathrm{m} 3]}\end{array}$ & $\begin{array}{c}\text { Chamberlet } \\
\text { Number }\end{array}$ & $\begin{array}{c}\text { First derivative of } \\
\text { Chamberlet Number }\end{array}$ \\
\hline Chamber24 & 616036 & 20 & 2 \\
\hline Chamber23 & 436396 & 18 & 2 \\
\hline Chamber22 & 340248 & 16 & 1 \\
\hline Chamber21 & 320512 & 15 & 0 \\
\hline Chamber20 & 329476 & 15 & 3 \\
\hline Chamber19 & 209108 & 12 & 2 \\
\hline Chamber18 & 230396 & 10 & 0 \\
\hline Chamber17 & 138604 & 10 & 1 \\
\hline Chamber16 & 162672 & 9 & 0 \\
\hline Chamber15 & 142944 & 9 & 0 \\
\hline Chamber14 & 106768 & 9 & 1 \\
\hline Chamber13 & 87572 & 8 & 2 \\
\hline Chamber12 & 80580 & 6 & 1 \\
\hline Chamber11 & 73188 & 5 & 1 \\
\hline Chamber10 & 60564 & 4 & 0 \\
\hline Chamber9 & 47572 & 4 & 2 \\
\hline Chamber8 & 39204 & 2 & 0 \\
\hline Chamber7 & 29132 & 2 & 0 \\
\hline Chamber6 & 22432 & 2 & 1 \\
\hline Chamber5 & 17712 & 1 & 0 \\
\hline Chamber4 & 8888 & 1 & 0 \\
\hline Chamber3 & 8392 & 1 & 0 \\
\hline Chamber2 & 7328 & 1 & 0 \\
\hline Chamber1 & 6136 & 1 & 1 \\
\hline proloculus & 13592 & 0 & 0 \\
\hline
\end{tabular}

symbionts as possible and keep photosynthesis of symbionts alive. Chamberlets may have a similar function as egg-holders, which are known from other symbiont bearing shallow benthic foraminifera (Hottinger, 1977b; Hottinger, 2006; Leutenegger, 1984). The connections between chamberlets and from one chamber to the next also enable the necessary exchange of metabolites and nutrients from the innermost of the cell to its surface at shortest possible distances (Hottinger, 1978). If the above reasons hold true, the onset of chamberlet formation during late nepionic stage just prior to adult growth might mark the moment of algal symbiont acquisition by the cell.

\section{Chamber Volume}

The chamber volume growth curve shows more variation than the curve of ray length versus spiral whorl number. Two minima of chamber volume can be recognized in the late adult portion of the test. Whether the strong decline of the volume of chamber \#48 is due to environmental disturbance or due to reproduction of the cell cannot be answered without observations of the living cell.

\section{Advantages of the Alveolinid Test Architecture}

In summary, the present high-resolution hard X-ray tomograms impressively illustrate the adaptive advantages of the planispiral-fusiform testarchitecture of the alveolinids in general. They are a compromise between increasing the surface/volume ratio and reducing the drag coefficient in environments showing turbulent water movements (Hohenegger, 1999). Division of chambers into chamberlets provides spots for hosting a maximum number of photosynthetizing endosymbionts. If 

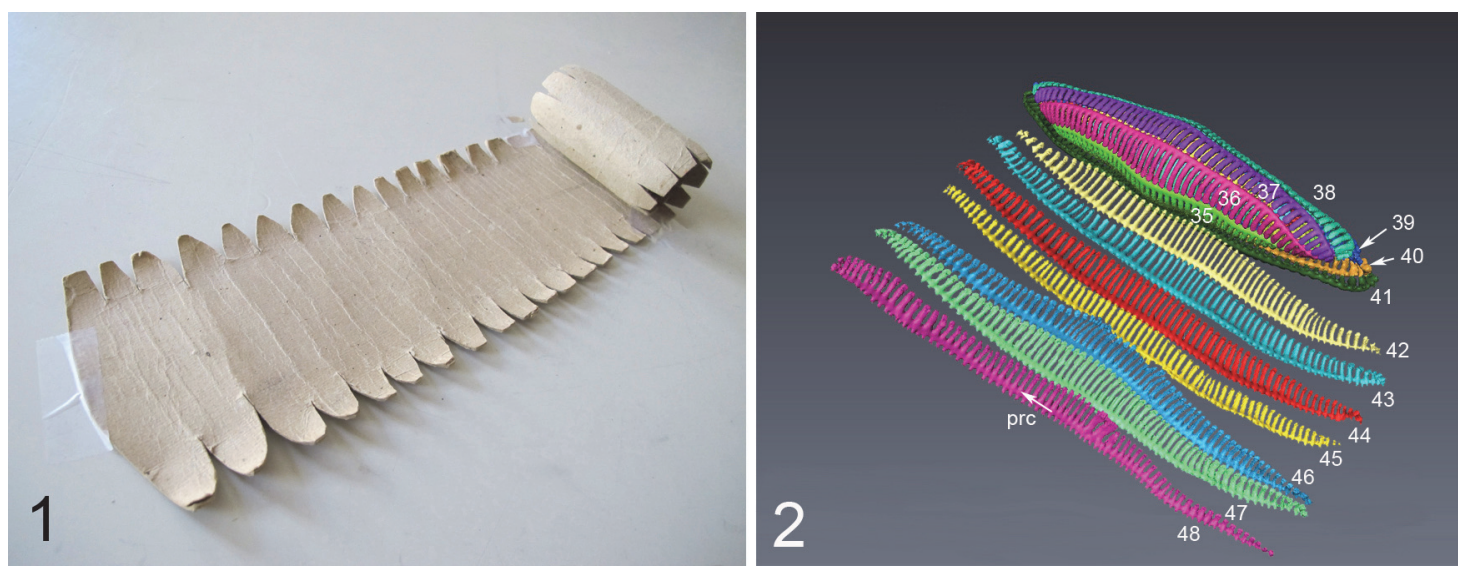

FIGURE 9. The cytoplasmic filling of a fusiform larger benthic foraminifer. 1, Cardboard model of a Loftusia fabricated by Manfred Reichel, deposited in the micropaleontological teaching collections at the Geological-Paleontological Institute, University of Basel. It illustrates schematically the long extension of the protoplasmic sheet when unrolled. Width of the cardboard sheet at the left end $=9 \mathrm{~cm}$, length of the cardboard sheet when completely unrolled $=80 \mathrm{~cm} .2$, Partially unfolded reconstructed cell of specimen 77023 of Borelis schlumbergeri investigated herein. The last seven chambers, i.e., \#42 to \#48, are unrolled. The colors correspond to those of the respected chamber numbers illustrated in Figures 4 and 5 . Note that the surface of the chambers become increasingly curved when getting more juvenile and, therefore, cannot be flattened without breaking up sutures between neighboring chambers. The same difficulty arises if one tries to flatten an orange peel into a plane. "prc" (flash) indicates the protoplasmic string connecting individual chamberlet fillings through the preseptal canal or passage of chamber \#48. Eventually, strings from neighboring chambers merge together at the polar ends of the cell (see inset in Figure 4.5).

unfolded and flattened, the cell of Borelis consists of a series of "spare-ribs" like shaped cytoplasmic sheets that are stringed together by longitudinal streams through the preseptal passages. Each sheet is packed in a chamber with "ribs" filling the chamberlets. Planispiral winding into a fusiform shape is a very efficient manner to squeeze the large cell into a compact and well organized body (see Figure 9).

Assuming a roughly triangular geometry of the plane cytoplasmic sheet when unfolded, with a base-line of $1995 \mu \mathrm{m}$ (length of the cell spindle), an upper estimate of about $20 \mu \mathrm{m}$ for the thickness of the protoplasmic sheet and encountering the measured void volume of the test of $103 \times 10^{6} \mu \mathrm{m}^{3}$ from the proloculus to chamber \#48, a length of the cytoplasmic sheet of at least $5 \mathrm{~mm}$ would result, which is huge for a foraminiferal protozoan.

In addition, preseptal passages can be seen as adaptations for optimized trans-chamber connection from one pole to the other while keeping the construction mechanically stable. This constructional concept guarantees not only for efficient exchange of nutrients and metabolites but also provides shelter for endosymbionts if light intensities become unfavorably high. Through rapid contraction of the cytoplasm through the various connec- tions endosymbionts are either passively dragged or can possibly actively escape from strong light exposure to a more interior portion of the cell if necessary. The serial arrangement of apertures allows pseudopodia to stream out for fixation of the test on sand particles or the substrate or for catchment of food particles.

\section{Methodological Remark}

Routine processing including 3D reconstruction and segmentation of a single specimen required a week or more, depending on size of the specimen but also whether chamber lumen was filled with sediment or not. The segmentation of empty chambers is very straightforward using the wand-tool of $A V I Z O$, whereas sedimentary infillings require manual cleaning of internal outlines of chambers, which can be time-consuming. Research projects attempting to investigate evolution of foraminifera by studying ontogenetic growth patterns on a larger number of specimens need to take this effort into account, i.e., treatment of 50 specimens per sample, a statistical minimum for a monospecific assemblage, would thus require a year of labor or an automated approach. Under any circumstances, $\mu C T$ of foraminiferal tests is an attractive tool to support or complement classical 
architectural studies and opens promising opportunities for the understanding of living and ancient foraminiferal life on the individual level and its calcification history.

\section{ACKNOWLEDGEMENTS}

The project was possible through financial support of the Stiftung zur Förderung des Naturhistorischen Museums Basel, Switzerland. The financial support of the Swiss National Science
Foundation in the frame of the R'Equip initiative (project number 316030_133802) is gratefully acknowledged. We thank $\bar{S}$. Schumacher (AlfredWegener-Institut, Bremerhaven, Germany) for her generous help to archive the data at PANGAEA. Thanks are given to C. Haug, P. Getty, J. Rumford and the team of Palaeontologia Electronica for their assistance and two anonymous reviewers for their critical comments on the manuscript.

\section{REFERENCES}

Abel, R.L., Rettondini Laurini, C., and Richter, M. 2012. A palaeobiologist's guide to 'virtual' micro-CT preparation. Palaeontologia Electronica, 15.2.6T:1-17. http://palaeoelectronica.org/content/issue-2-2012-technical-articles/233-micro-ct-workflow

Bé, A.W.H., Jongbloed, W.L., McIntyre, A. 1969. X-Ray microscopy of Recent planktonic foraminifera. Journal of Paleontology, 43(6):1384-1396.

Branson, O. 2014. The Biomineralogy of Marine Calcifying Organisms and Palaeoproxies. Unpublished PhD Thesis, University of Cambridge, Department of Earth Sciences, Jesus College, U.K. http://eprints.esc.cam.ac.uk/id/eprint/3056

Briguglio, A., Hohenegger, J., and Less, G. 2013. Paleobiological applications of threedimensional biometry on larger benthic foraminifera: A new route to discoveries. Journal of Foraminiferal Research, 43(1):72-87. https://doi.org/10.2113.gsjfr.43.1.72

Briguglio, A., Kinoshita, S., Wolfgring, E., and Hohenegger, J. 2016. Morphological variations in Cycloclypeus carpenteri: Multiple embryos and multiple equatorial layers. Palaeontologia Electronica 19.1.3A:1-22. http://palaeo-electronica.org/content/2016/1404-morphology-of-ccarpenteri

Briguglio, A., Metscher, B., and Hohenegger, J. 2011. Growth rate biometric quantification by Xray microtomography on larger benthic foraminifera: Three-dimensional measurements push nummulitids into the fourth dimension. Turkish Journal of Earth Sciences, 20:683-699. https:/ /doi.org/10.3906/yer-0910-44

Brown, K. 2007. Biogeographic and Morphological Variation in Late Pleistocene to Holocene Globorotalid Foraminifera. Unpublished PhD dissertation, Phil. Nat. Fakultät, University of Basel, Switzerland. http://edoc.unibas.ch/diss/DissB_8290/

Brummer, G.-J.A. and Kroon, D. 1988. Planktonic foraminifers as tracers of ocean-climate history. Ph.D. Dissertation, Free University Press, Amsterdam, The Netherlands.

Carpenter, W.B., Parker, W.K., and Jones, R. 1862. Introduction to the Study of the Foraminifera. Ray Society London, U.K.

Caus, E., Parente, M., Vicedo, V., Frija, G., and Martinez, R. 2013. Broeckina gassoensis sp. nov., a larger foraminiferal index fossil for the middle Coniacian shallow-water deposits of the Pyrenean Basin (NE Spain). Cretaceous Research, 45:76-90. https://doi.org/10.1016/ j.cretres.2013.08.002

Cunningham, J.A., Rahman, I.A., Lautenschlager, S., Rayfield, E.J., and Philip C.J. Donoghue, P.C.J. 2014. A virtual world of paleontology. Trends in Ecology \& Evolution, 29(6):347-357. https://doi.org/10.1016/j.tree.2014.04.004

Cnudde, V. and Boone, M.N. 2013. High-resolution X-ray computed tomography in geosciences: A review of the current technology and applications. Earth Science Reviews, 123:1-17. https://doi.org/10.1016/j.earscirev.2013.04.003

D'Orbigny, A. 1839. Foraminifères. In De La Sagra, M.R. Histoire Physique, Politique, et Naturelle de l'lle de Cuba. Arthus Bertrand, Editeur, Libraire de la Société de Géographie et de la Société Royale des Antiquaires du Nord, Rue Hautefeuille, 23, Paris:1-224 (Text) / (Atlas):12 plates. 
Drooger, C.W. 1952. Study of American Miogypsinidae. Ph.D. Dissertation University of Utrecht, Von K \& Co's Drukkerij, Zeist, The Netherlands.

Drooger, C.W. 1984. Evolutionary patterns in lineages of orbitoidal foraminifera. Proceedings of the Koninklijke Nederlandse Akademie van Wetenschappen, Ser. B, 87(1):103-130.

Ehrenberg, C.G. 1839. Über die Bildung der Kreidefelsen und des Kreidemergels durch unsichtbare Organismen. Abhandlungen der Königlichen Akademie der Wissenschaften zu Berlin, Physikalische Klasse, 1838:59-147.

Ferràndez-Cañadell, C., Briguglio, A., Hohenegger, J., and Wöger, J. 2014. Test fusion in adult foraminifera: A review with new observations of an early Eocene Nummulites specimen. Journal of Foraminiferal Research, 44(3):316-324. https://doi.org/10.2113/gsjfr.44.3.316

Görög, A., Szinger, B., Tóth, E., and Viszkok, J. 2012. Methodology of the micro-computer tomography on foraminifera. Palaeontologia Electronica, 15.1.3T:1-15. https://palaeoelectronica.org/content/issue1-2012technical-articles/121-methodology-of-ct-on-forams.

Green, O.R. 2001. A Manual of Practical Laboratory and Field Techniques in Palaeobiology. Springer, Dordrecht. https://doi.org/10.1007/978-94-017-0581-3

Hedley, R.H. 1957. Microradiography applied to the study of foraminifera. Micropaleontology, 3(1):19-28. https://doi.org/10.2307/1484325

Hofker, J. 1933. Foraminifera of the Malay Archipelago. Papers from Dr. Th. Mortensen's Pacific Expedition 1914-16. Videnskabelige Meddelelser Dansk Naturhistorisk Forening, 93:71-67.

Hofker, J. 1966. Foraminifera from the Cretaceous of South Limburg, Netherlands, LXXXII. Once again Linderina visserae Hofker. Overdruk uit het Natuurhistorisch Maandblad, 55e Jaargang (1):13-15.

Hofker, J. Sr. 1969. An analysis of the subfamily Notorotaliinae (Foraminifera) Hornibrook, 1961. New Zealand Journal of Geology and Geophysics, 12(2):460-483. https://doi.org/10.1080/ 00288306.1969.10420293

Hoffmann, R., Schultz, J.A., Schellhorn, R, Rybacki, E., Keupp, H., Gerden, S.R., Lemanis, R., and Zachow, S. 2014. Non-invasive imaging methods applied to neo- and paleoontological cephalopod research. Biogeosciences, 11:2721-2739. https://doi.org/10.5194/bg-11-27212014

Hohenegger, J. 1999. Larger Foraminifera - microscopical greenhouses indicating shallowwater tropical and subtropical environments in the present and past. Kagoshima University Research Center for the Pacific Islands, Occasional Papers, 32:19-45. https://ci.nii.ac.jp/ naid/120005231849/

Hohenegger, J. 2009. Functional shell geometry of symbiont-bearing benthic foraminifera. Galaxea, Journal of Coral Reef Studies, 11:81-89. https://doi.org/10.3755/galaxea.11.81

Hottinger, L. 1960. Recherches sur les Alvéolines du Paléocène et de l'Eocène. Mémoires Suisses de Paléontologie 75:1-243 (Text) / 76 (Atlas):18 plates.

Hottinger, L. 1963. Les alvéolines paléogènes, exemple d'un genre polyphylétique, pp. 298-314. In Von Koenigswald, G.H.R., Emeis, J.D., Buning, W.L., Wagner, C.W. (eds.). Evolutionary Trends in Foraminifera. Elsevier Publishing Company, Amsterdam, The Netherlands.

Hottinger, L. 1967. Foraminifères imperforés du Mésozoïque marocain. Editions du Service géologique du Maroc, Rabat - 1967, pour le compte du Royaume du Maroc, Ministère du commerce, de l'artisanat, de l'industrie et des mines, Direction des Mines et de la Géologie, Division de la Géologie, Notes et Mémoires du Service Géologique 209:1-168.

Hottinger, L. 1974. Alveolinids, Cretaceous-Tertiary larger Foraminifera. Esso Production Research-European Laboratories, Vol. EPR-E-1 SP74:1-84.

Hottinger, L. 1977a. Distribution of larger Peneroplidae, Borelis and Nummulitidae in the Gulf of Elat, Red Sea. Utrecht Micropaleontological Bulletins, 15:35-110.

Hottinger, L. 1977b. Foraminifères operculiniformes. Mémoires Museum National d'Histoire Naturelle, Série C - Sciences de la Terre, 40:1-159.

Hottinger, L. 1978. Comparative anatomy of elementary shell structures in selected larger foraminifera, pp. 203-266. In Hedley, R.H. and Adams, C.G. (eds.). Foraminifera. Volume 3. Academic Press, London, U.K.

Hottinger, L. 1979. Araldit als Helfer in der Mikropaläontologie. Ciba-Geigy Aspekte, 3:1-10.

Hottinger, L. 1983. Foraminifères de grand taille: Significance des structures complexes de la coquille. Benthos'83, 2nd Int. Symp. Benthic Foraminifera (Pau, April 1983):309-315. Pau and Bordeaux, March 1984.

Hottinger, L., Mehl, J., and Pecheux, J.F. 1991. X-Ray microscopy in micropalaeontology. Microscopy and Analysis, 21:21-23. 
Hottinger, L., Halicz, E., and Reiss, Z. 1993. Recent foraminiferda from the Gulf of Aqaba, Red Sea. Slovenska Akademija Znanosti in Umetnosti, Ljubliana, Classis IV, Historia Naturalis, Opera, 33:1-179.

Hottinger, L. and Leutenegger, S. 1980. The structure of calcarinid foraminifera. Schweizerische Paläontologische Abhandlungen, 101:115-154.

Hottinger, L., Reiss, Z., and Langer, M. 2001. Spiral canals of some Elphidiidae. Micropaleontology, 47(supplement 2):5-34. https://www.jstor.org/stable/1486160

Hottinger L. 2006.- Illustrated glossary of terms used in foraminiferal research.- Carnets de Géologie - Notebooks on Geology, Brest, Memoir 2006/02 (CG2006_M02):1-126. http:// paleopolis.rediris.es/cg/CG2006_M02/index.html

Johnstone, H.J.H. and Barker, S. $20 \overline{1} 0$. Inside story: An X-ray computed tomography method for assessing dissolution in the tests of planktonic foraminifera. Marine Micropaleontology, 77:58-70. https://doi.org/10.1016/j.marmicro.2010.07.004

Langer, W. 1975. Die Kontaktmikroradiographie in der Mikropaläontologie. Decheniana, 127:215-219.

Langer, M. and Hottinger, L. 2000. Biogeography of selected "larger" foraminifera. Micropaleontology, 46 (suppl. 1):105-126. https://www.jstor.org/stable/1486184

Leary, P.N. and Hart, M.B. 1988. X-raying planktonic foraminifera. Journal of Micropalaeontology, 7(1):43-44. https://doi.org/10.1144/jm.7.1.43

Leutenegger, S. 1984. Symbiosis in benthic foraminifera: Specificity and host adaptations. Journal of Foraminiferal Research, 14:16-35. https://doi.org/10.2113/gsjfr.14.1.16

Mary, Y. 2013. Morphologic, Biogeographic and Ontogenetic Investigation of Mid-Pliocene Menardellids (planktonic foraminifera). Unpublished PhD dissertation, University of Basel, Switzerland. http://edoc.unibas.ch/diss/DissB_10611/. https://doi.org/10.5451/unibas006194467

Masschaele, B.C., Cnudde, V., Dierick, M., Jacobs, P., Van Hoorebeke, L., and Vlassenbroeck, J. 2007. UGCT: New X-ray radiography and tomography facility. Nuclear Instruments and Methods in Physics Research, Series A, 580(1):266-269. https://doi.org/10.1016/ j.nima.2007.05.099

Mehl, J.O. and Noe, S.U. 1990. Morphological investigations of Miliolidae (Foraminifera) from the Upper Permian of the Southeastern Alps, based on thin sections and stereoscopic X-ray microradiographs. Paläontologische Zeitschrift, 64:173-192. https://doi.org/10.1007/ BF02985712

O'Herne, L. 1972. Secondary chamberlets in Cycloclypeus. Scripta Geologica, 7:1-35.

Reichel, M. 1931. Sur la structure des Alvéolines. Eclogae Geologicae Helvetiae, 24(2):289-303.

Reichel, M. 1933. Sur une Alvéoline cénomanienne du Bassin du Beausset. Eclogae Geologicae Helvetiae, 26(2):269-280.

Reichel, M. 1937. Etude sur les Alvéolines. Mémoires de la Société paléontologique Suisse, 5759:1-147.

Reichel, M. 1941. Sur un nuveau genre d'Alvéolines du Crétacé supérieur. Eclogae Geologicae Helvetiae, 34(2):254-260.

Reichel, M. 1953. Les charactères embryonnaires de Subalvéolina. Eclogae Geologicae Helvetiae, 46(2):256-262.

Reiss, Z. and Hottinger, L. 1984. The Gulf of Aqaba. Ecological micropaleontology. Springer Verlag.

Renema, W. 2002. Larger foraminifera as marine environmental indicators. Scripta Geologica, 124:1-260.

Sasaki, O., Iwashita, T., Kano, H., Ishida, Y., Konno, H., and Hayashi, H. 2008. e-Foram Stock at Tohoku University Museum. http://webdb2.museum.tohoku.ac.jp/e-foram/

Schaub, H. 1981. Nummulites et assilines de la Téthys paléogène. Taxinomie, phylogénèse et biostratigraphie. Schweizerische Paläontologische Abhandlungen, 3 volumes, 104:1-236, 105 (Atlas I):Plates 1-48, 106 (Atlas II):Plates 49-97. Birkhäuser.

Schindelin, J., Arganda-Carreras, I., Frise, E., Kaynig, V., Longair, M., Pietzsch, T., Preibisch, S., Rueden, C., Saalfeld, S., Schmid, B., Tinevez, J.-Y., While, D.J., Hartenstein, V., Eliceiri, K., Tomancak, P., and Cardona, A. 2012. Fiji - an open source platform for biological image analysis. Nature Methods, 97(7):676-682. https://doi.org/10.1038/nmeth.2019

Schmidt, D., Rayfield, E., Cocking, A., and Marone, F. 2013. Linking evolution and development: Synchrotron Radiation X-Ray tomographic microscopy of planktic foraminifers. Palaeontology, 56(4):741-749. https://doi.org/10.1111/pala.12013 
Schroeder, R. 1975. General evolutionary trends in Orbitolinas. Revista Espanola de Micropaleontologia (Numero Especial):117-128.

Sirel, E. and Acar, S. 1982. Praebullalveolina, a new foraminiferal genus from the Upper Eocene of the Afyon and Canakkale region (west of Turkey). Eclogae Geologicae Helvetiae, 75(3):821-839.

Speijer, R.P., Van Loo, D., Masschaele, B., Vlassenbroeck, J., Cnudde, V., and Jacobs, P. 2008. Quantifying foraminiferal growth with high-resolution X-ray computed tomography: New opportunities in foraminiferal ontogeny, phylogeny, and paleoceanographic applications. Geosphere, 4(4):760-763. https://doi.org/10.1130/GES00176.1

Ter Kuile, B. and Erez, J. 1984. In situ growth rate experiments on the symbiont-bearing foraminifera Amphistegina lobifera and Amphisorus hemprichii. Journal of Foraminiferal Research, 14(4):262-276. https://doi.org/10.2113/gsjfr.14.4.262

Van Gorsel, J.T. 1975. Evolutionary trends and stratigraphic significance of the Late Cretaceous Helicorbitoides-Lepidorbitoides lineage. Utrecht Micropaleontological Bulletins, 12:1-100. https://dspace.library.uu.nl/handle/1874/205816

Van der Vlerk, I.M. and Umbrove, J.H.F. 1927. Tertiaire gidsforaminiferen van Nederlands-OostIndie. Dienst van den Mijnbouw in Nederlandsch-Indie Wetenschappelijke Mededelingen, 6:1-35.

Van der Vlerk, I.M. and Gloor, H. 1968. Evolution of an embryo. Genetica., Nederlands Tijdschrift voor Erfelijksheids - en Afstammingsleer, 39(Afl. 1):45-63. https://doi.org/10.1007/ BF02324455

Vicedo, V., Aguilar, M., Caus, E., and Hottinger, L. 2009. Fusiform and laterally compressed alveolinaceans (Foraminiferida) from both sides of the Late Cretaceous Atlantic. Neues Jahrbuch für Geologie und Paläontologie - Abhandlungen, 253(2-3):229-247. https://doi.org/ 10.1127/0077-7749/2009/0253-0229

Vicedo, V., Berlanga, J.A., Serra-Kiel, J., and Caus, E. 2013. Architecture and age of the foraminiferal genus Taberina Keijzer, 1945. Journal of Foraminiferal Research, 43(2):170181. https://doi.org/10.2113/gsjfr.43.2.170

Vicedo, V. and Piuz, A. 2017. Evolutionary trends and biostratigraphical application of new Cenomanian alveolinoids (Foraminifera) from the Natih Formation of Oman. Journal of Systematic Palaeontology, 15(10):821-850. https://doi.org/10.1080/14772019.2016.1244709 Von Koenigswald, G.H.R., Emeis, J.D., Buning, W.L., Wagner, C.W. 1963. Evolutionary Trends in Foraminifera. Elsevier Publishing Company, Amsterdam, The Netherlands. 


\section{APPENDIX CAPTIONS}

APPENDIX 1. Video showing the complete sequence of chamber addition in Borelis schlumbergeri specimen 77023-1. Same color coding for chambers as in Figures 4, 5 and 9.2. VLC media file, size $=302509 \mathrm{~KB}$. The file can be downloaded as supplementary data (filename=Animation7.avi) at https://doi.org/10.1594/PANGAEA.884663.

APPENDIX 2. Animated stack of axial slices through the test of Borelis schlumbergeri specimen 77023-1 obtained with Voxler software. VLC media file, size $=2567 \mathrm{~KB}$. See Appendix 3 for a version in gif format. The file can be downloaded as supplementary data (Filename=Video_Voxler_Borelis.avi) at https://doi.org/10.1594/PANGAEA.884663.

APPENDIX 3. Same animated stack as in Appendix 2, but in form of a gif animation. IrfanView gif file, size $=8324 \mathrm{~KB}$. The file can be downloaded as supplementary data (Filename=Borelis_Voxler.gif) at https://doi.org/10.1594/PANGAEA.884663.

APPENDIX 4. High resolution version to the video shown in Appendix 1. Same color coding for chambers as in Figures 4, 5 and 9.2. VLC media file, size $=322592 \mathrm{~KB}$. The file can be downloaded as supplementary data (Filename=Borelis_Animation.mpg) at https://doi.org/10.1594/PANGAEA.884663.

APPENDIX 5. Low resolution animation combining of axial sections and lateral views of chamber additions of Borelis schlumbergeri specimen 77023-1, from adult to juvenile stages. Same color coding for chambers as in Figures 4, 5 and 9.2. VLC media file, size $=19568 \mathrm{~KB}$. The file can be downloaded as supplementary data (Filename=Animation1.mpg) at https://doi.org/10.1594/PANGAEA.884663.

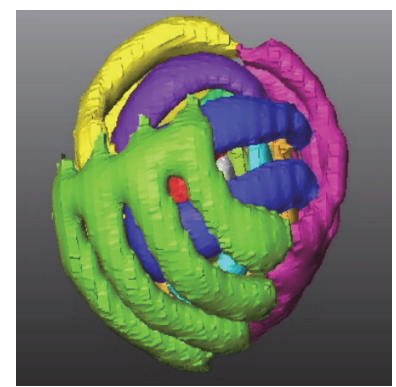

Appendix 1 and 4.

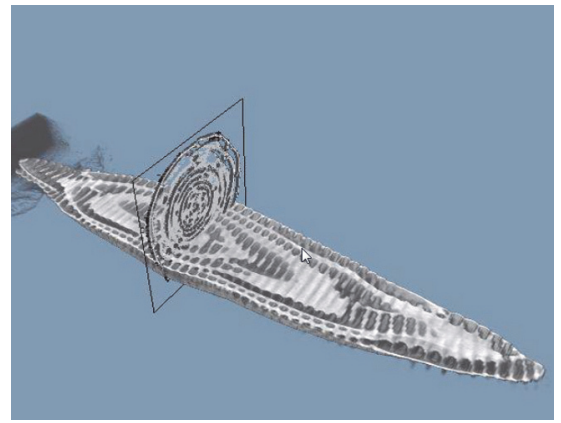

Appendix 2 and 3.

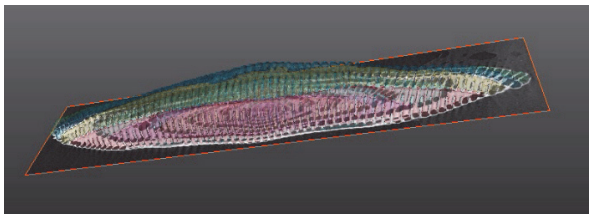

Appendix 5. 